\title{
Bryozoans from the Jurginskaya Formation (Famennian, Upper Devonian) of the Tom-Kolyvansk area (Western Siberia, Russia)
}

\author{
Zoya Tolokonnikova
}

Kuzbass State Pedagogical Academy, Kuznetsov Str. 6, 654041 Novokuznetsk, Russia; e-mail: zalatoi@yandex.ru

\begin{abstract}
Nine bryozoan species are described from the Jurginskaya Formation (Famennian, Late Devonian) from Western Siberia, Russia, namely: Leptotrypella pojarkovi Orlovski, 1961, Rhombopora subtilis Nekhoroshev, 1977, Klaucena lalolamina Yang, Hu, Xia, 1988, Eofistulotrypa famennensis sp. n., Atactotoechus cellatus sp. n., Nikiforopora jurgensis sp. n., Eridotrypella tyzhnovi sp. n., Mediapora elegans sp. n., and Klaucena gracilis sp. n. The studied assemblage shows palaeogeographical affinity with Kazakhstan, Kirgizia, Transcaucasia, China, and the United States of America.
\end{abstract}

Keywords: Bryozoa, Late Devonian, Western Siberia, Russia

\section{Introduction}

The sedimentary Jurginskaya Formation spreads on the eastern periphery of the TomKolyvansk area (south of Western Siberia, Russia). The age of the formation is Middle-Late Famennian, based on stratigraphy, lithology and fossils (Kraevskaya, 1960; Babin et al., 1999; Gutak \& Tolokonnikova, 2010). The first bryozoan fauna was discovered in the 1940s, but without a detailed description (Kraevskaya, 1960). Bryozoans outnumber the other fossils (brachiopods, crinoids, cephalopods, bivalves). The bryozoan assemblage consists of cystoporates (Eofistulotrypa famennensis sp. n.), trepostomes (the already known species Leptotrypella pojarkovi Orlovski, 1961, and three new species: Atactotoechus cellatus sp. n., Nikiforopora jurgensis sp. n., Eridotrypella tyzhnovi sp. n.), as well as rhabdomesines (two already known species Rhombopora subtilis Nekhoroshev, 1977, and
Klaucena lalolamina Yang, $\mathrm{Hu}, \mathrm{Xia}, 1988$; and two new species: Mediapora elegans sp. n., and Klaucena gracilis sp. n.).

\section{Methods and material}

The material for the present study was collected during the summer of 2008 in the type section of the Jurginskaya Formation on the right bank of the Tom River near the town of Jurga in the Kemerovo region (Fig. 1). The bryozoans were found at three localities, mainly in shales, rarely in calcareous sandstones and siliceous limestones. They were investigated in thin section using a binocular microscope. A total of 103 thin sections were studied.

The morphological terminology is adopted from Astrova (1978) and Boardman et al. (1983). The taxonomic descriptions of the bryozoan fauna are based on measurements of the 


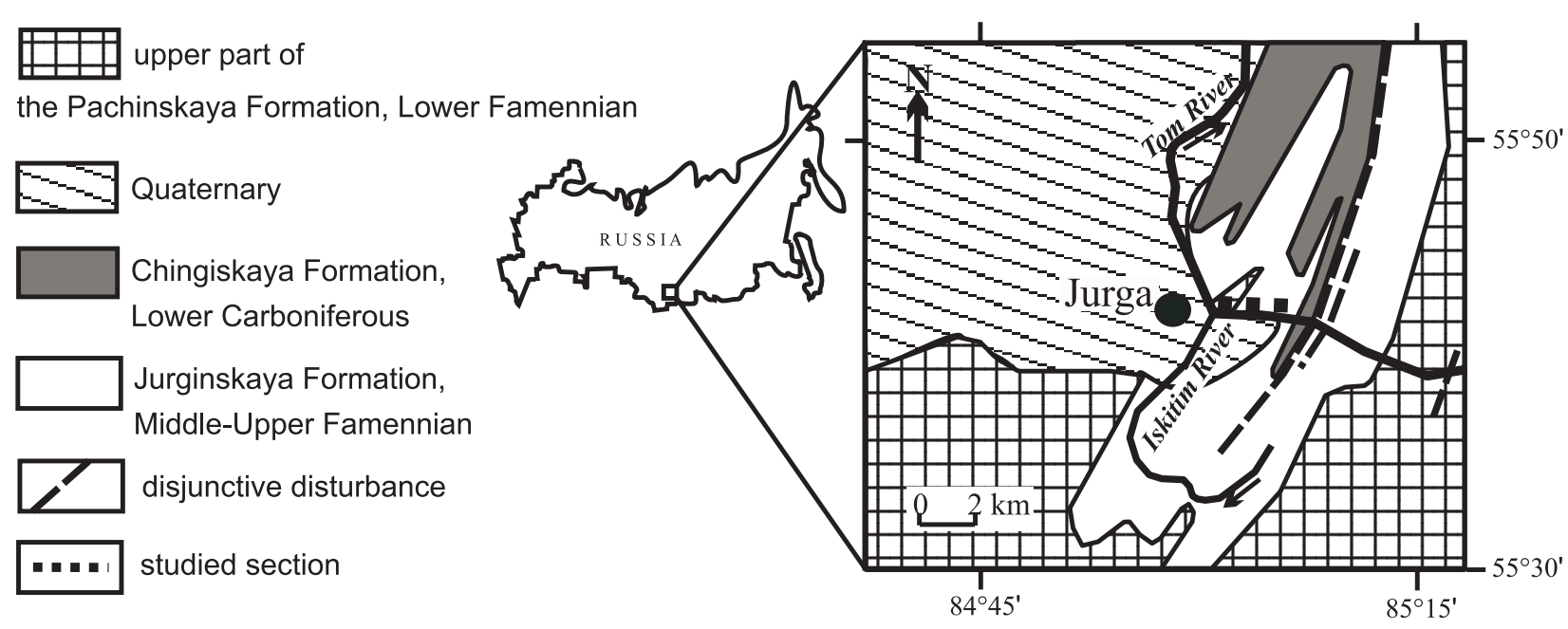

Fig. 1. Scheme of spreading of deposits of the Jurginskaya Formation (compiled on unpublished data of Tyzhnov, 1943).

morphological characteristics. The inner diameter was measured for hollow characteristics such as apertures and autozooecial chambers. The spacing of the morphological characteristics at the colony surface was measured from the centre to the next centre of the apertures. Additional quantitative characteristics studied are the number of exilazooecia and the acanthostyles surrounding each autozooecial aperture. The spacing of the horizontal structures such as diaphragms was quantified by counting their number in $1 \mathrm{~mm}$ of the length of the host autozooecium. Numerical statistical values (mean, standard deviation, variation coefficient, and minimum/maximum values) were calculated following Köhler et al. (1996).

The described material is stored at the Kuzbass State Pedagogical Academy (Novokuznetsk, Russia; collection number 4).

\section{Systematic palaeontology}

Phylum Bryozoa Ehrenberg, 1831

Class Stenolaemata Borg, 1926

Order Cystoporata Astrova, 1964

Suborder Fistuliporina Astrova, 1964

Family Fistuliporidae Ulrich, 1882

Genus Eofistulotrypa Morozova, 1959

Type species: Eofistulotrypa manifesta Morozova, 1959, Frasnian (Late Devonian), Kuzbass (Russia).
Diagnosis: colonies ramose. Autozooecia with diaphragms. Apertures circular-oval, possessing well-developed lunaria. Vesicles in exozone only.

Occurrence: China, Russia, Mongolia; MiddleLate Devonian.

Discussion: Eofistulotrypa Morozova, 1959 differs from Fistulotrypa Bassler, 1929 in the absence of vesicular tissue in the endozone.

Eofistulotrypa famennensis sp. nov. (Figs. 2 A-C; Table 1)

Etymology: referring to the Famennian in which this species was found.

Holotype: 4/18.1; paratype: 4/18.2.

Type locality: Tom River, Kemerovo region, Russia.

Type horizon: Jurginskaya Formation, Podonino horizon, Middle-Late Famennian (Late Devonian).

Diagnosis: colonies ramose with self-incrustation. Apertures circular, large; lunaria weakly developed. Vesicles 2-3 rows, developed in exozones only.

Description: colonies are ramose with secondary overgrowth. Branches 10-18 mm in diameter, secondary overgrowths $5-7 \mathrm{~mm}$ thick. Endozones 4-5 mm wide, exozones 3-6 mm wide. Autozooecial walls $0.012 \mathrm{~mm}$ thick in endozones, $0.025 \mathrm{~mm}$ thick in exozones. Autozooecial diaphragms straight or inclined, numbering 1-2 on $1 \mathrm{~mm}$ of autozooecial length in endozones and 3-5 on $1 \mathrm{~mm}$ in exozones. Au- 
Table 1. Descriptive statistics for Eofistulotrypa famennensis sp. nov.

\begin{tabular}{lcccccc}
\hline Eofistulotrypa famennensis sp. nov. & $\mathrm{N}$ & $\mathrm{X}$ & $\mathrm{SD}$ & $\mathrm{CV}$ & $\mathrm{MIN}$ & $\mathrm{MAX}$ \\
\hline aperture width [mm] & 20 & 0.30 & 0.029 & 9.70 & 0.270 & 0.37 \\
aperture spacing from centre to centre [mm] & 15 & 0.45 & 0.065 & 14.47 & 0.350 & 0.57 \\
lunaria length [mm] & 10 & 0.03 & 0.012 & 37.10 & 0.025 & 0.05 \\
lunaria width [mm] & 10 & 0.09 & 0.018 & 20.60 & 0.075 & 0.12 \\
vesicles per 1 mm] & 10 & 2.35 & 0.337 & 14.36 & 2.000 & 3.00 \\
diameter of vesicles [mm] & 10 & 0.17 & 0.036 & 20.30 & 0.120 & 0.25 \\
\hline
\end{tabular}

Abbreviations: $\mathrm{N}=$ number of measurements, $\mathrm{X}=$ mean, $\mathrm{SD}=$ standard deviation, $\mathrm{CV}=$ coefficient of variation, $\mathrm{MIN}=$ minimal value, $\mathrm{MAX}=$ maximal value .

tozooecial apertures circular. Lunaria weakly developed, $0.025 \mathrm{~mm}$ thick in the middle part. Vesicles large, abundant, arranged in 2-3 rows, rarely in 5 rows between autozooecia, polygonal in tangential section.

Discussion: Eofistulotrypa famennensis sp. nov. is similar to Eofistulipora primacylindilla Xia, 1997 from the Famennian of Xinijang, China (crepida Conodont Zone), but differs in colony form (ramose with secondary overgrowth versus ramose with central zooecia in Eofistulipora primacylindilla). The apertures are circular and the width of 0.27-0.37 mm in Eofistulotrypa famennensis is different in Eofistulipora primacylindilla, which shows an oval shape of $0.14-0.2 \mathrm{~mm}$ in width and $0.23-0.28 \mathrm{~mm}$ in length.

Order Trepostomata Ulrich, 1882

Suborder Amplexoporina Astrova, 1965

Family Atactotoechidae Duncan, 1939

Genus: Atactotoechus Duncan, 1939

Type species: Atactotoechus typicus Duncan, 1939, Traverse Group (Middle Devonian), United States of America.

Diagnosis: colonies encrusting, massive or branched. Autozooecia with polygonal to cir- cular-polygonal apertures. Diaphragms abundant, straight or inclined. Cystiphragms single or several in cluster. Exilazooecia rare. Acanthostyles absent or present in small numbers in maculae. Autozooecial walls thin in the endozone; irregularly thickened, finely laminated in the exozone (modified after Astrova, 1978).

Occurrence: worldwide; Early Silurian to Late Devonian.

Discussion: Atactotoechus Duncan, 1939 differs from Orbignyella Ulrich \& Bassler, 1904 in having thickened autozooecial walls and absence of acanthostyles.

Atactotoechus cellatus sp. nov. (Figs. 2 D-F; Table 2)

Etymology: the specific name 'cellatus' refers to the view of surface colony in tangential section (derived from Latin 'cella' = cell).

Holotype: 4/19.1; paratypes: 4/19.2-4/19.5.

Type locality: Tom River, Kemerovo region, Russia.

Type horizon: Jurginskaya Formation, Podonino horizon, Middle-Late Famennian (Late Devonian).

Diagnosis: colonies branched and encrusting. Apertures circular-polygonal; exilazooecia

Table 2. Descriptive statistics for Atactotoechus cellatus sp. nov. (for abbreviations, see Table 1).

\begin{tabular}{lcccccc}
\hline Atactotoechus cellatus sp. nov. & $\mathrm{N}$ & $\mathrm{X}$ & $\mathrm{SD}$ & $\mathrm{CV}$ & $\mathrm{MIN}$ & $\mathrm{MAX}$ \\
\hline branch width [mm] & 6 & 10.33 & 0.605 & 5.85 & 9.500 & 11.00 \\
endozone width [mm] & 10 & 3.75 & 0.205 & 5.45 & 3.500 & 4.00 \\
exozone width [mm] & 10 & 3.25 & 0.227 & 6.99 & 3.000 & 3.50 \\
aperture width [mm] & 20 & 0.19 & 0.042 & 21.55 & 0.120 & 0.27 \\
exilazooecia width [mm] & 10 & 0.07 & 0.018 & 25.44 & 0.050 & 0.10 \\
acanthostyle diameter [mm] & 10 & 0.04 & 0.013 & 35.13 & 0.025 & 0.05 \\
\hline
\end{tabular}



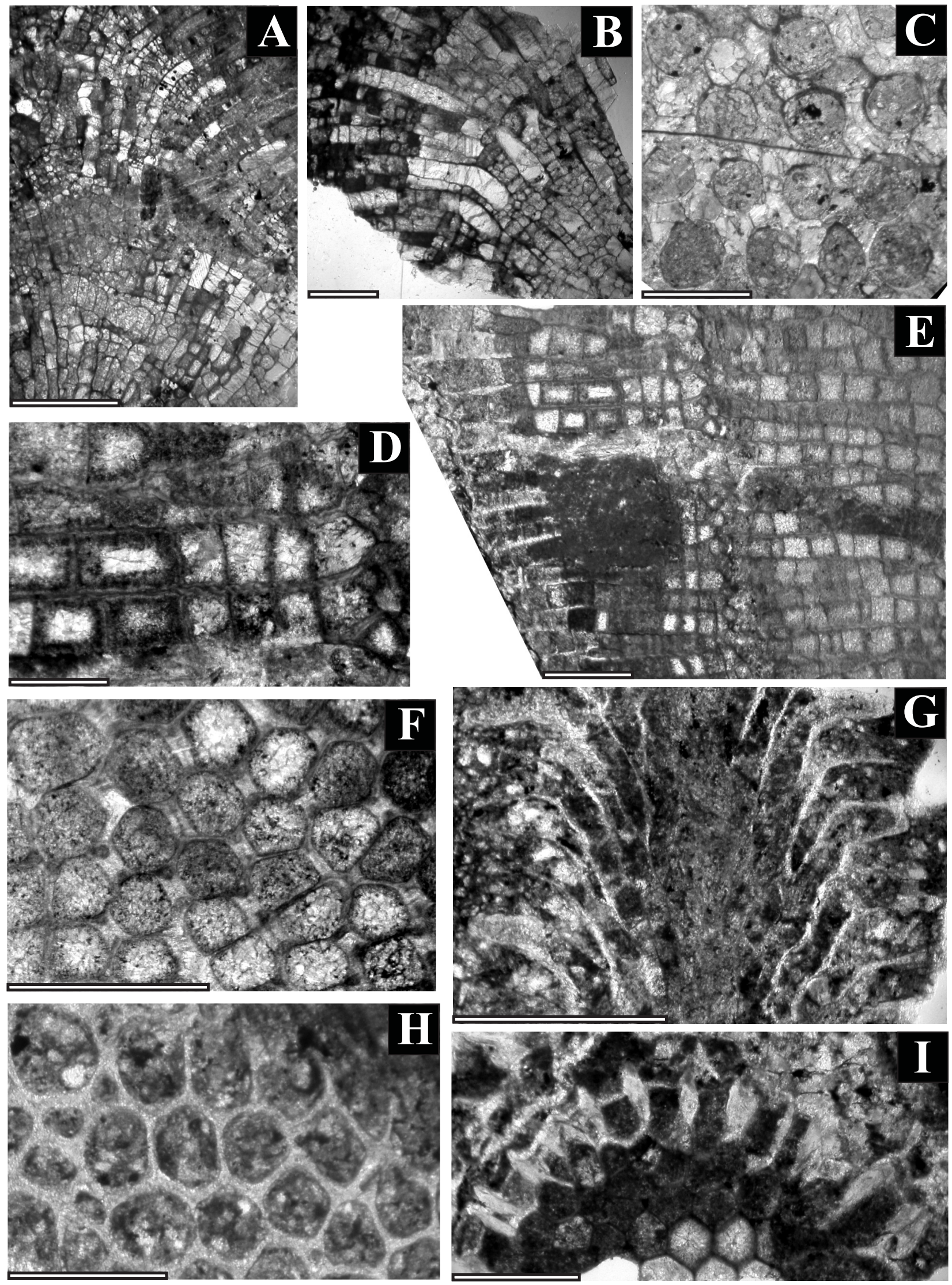
rare and short or 4-5 in cluster around each aperture; acanthostyles absent or 3-5 around aperture.

Description: colonies branched and encrusting. Encrusting colonies 4-6 mm thick (usually it has two layers of incrustation: first 1-2 mm thick and second 3-4 mm thick). Autozooecial walls twisted, $0.075 \mathrm{~mm}$ thick in exozones. Autozooecial diaphragms rare in endozones, abundant in exozones, straight or inclined. Autozooecial diaphragms 4-5 per $1 \mathrm{~mm}$. Cystiphragms rare. Autozooecial apertures circular-polygonal. In any direction 7-8 apertures in $2 \mathrm{~mm}$. Exilazooecia rare, short, polygonal in cross-section. Sometimes 4-5 exilazooecia surrounding autozooecial aperture. Acanthostyles short, locally abundant, 3-5 surrounding each aperture, in some place absent.

Discussion: Atactotoechus cellatus sp. nov. is similar to Atactotoechus solus Troitzkaya, 1968 from the Famennian of central Kazakhstan. The new species differs in colony form, which is massive in A. solus, the wall thickness in exozone of A. cellatus has $0.075 \mathrm{~mm}$ vs. $0.02 \mathrm{~mm}$ in A. solus, size and number of acanthostyles (3-5 acanthostyles of $0.025-0.05 \mathrm{~mm}$ in diameter vs. 1-2 acanthostyles of $0.02 \mathrm{~mm}$ in diameter in $A$. solus).

Genus Leptotrypella Vinassa de Regny, 1921 Type species: Chaetetes barrandei Nicholson, 1874, Middle Devonian, Canada.
Diagnosis: colonies branched. Autozooecia with polygonal to circular-polygonal apertures. Autozooecial diaphragms lacking in endozone; rare to common in exozone. Exilazooecia rare. Acanthostyles long, common to abundant. Autozooecial walls granular, thin in the endozone; laminated, irregularly thickened in exozones (modified after Astrova, 1978).

Occurrence: worldwide; Middle Silurian to Early Carboniferous.

Discussion: Leptotrypella Vinassa de Regny, 1921 differs from Leptotrypa Ulrich, 1883 in having a branched colony, and from Anomalotoechus Duncan, 1939 in having a branched colony and absence of diaphragms in endozones.

Leptotrypella pojarkovi Orlovski, 1961 (Figs. 2 G-H; Table 3)

1961 Leptotrypella pojarkovi sp. nov., Orlovski, pp. 67-68, pl. 8, fig. 5.

Material: 4/20a, 4/20b.

Description: colonies branched. Exozones 0.87$1 \mathrm{~mm}$ wide. Autozooecial walls of $0.025 \mathrm{~mm}$ thick in endozones. Autozooecial diaphragms straight or inclined, 1-2 in number. Autozooecial apertures circular-polygonal, sometimes oval. Exilazooecia polygonal, arranged single or in groups of 3-4. Acanthostyles located at junctions of zooecial apertures.

Occurrence: Kirgizia, Republic of Nakhichevan (Azerbaijan): the Early-Middle Famennian (Late Devonian); Kemerovo region, Russia:

Table 3. Descriptive statistics for Leptotrypella pojarkovi Orlovski, 1961. (for abbreviations, see Table 1).

\begin{tabular}{lrccccc}
\hline Leptotrypella pojarkovi Orlovski, 1961 & $\mathrm{N}$ & $\mathrm{X}$ & $\mathrm{SD}$ & $\mathrm{CV}$ & $\mathrm{MIN}$ & $\mathrm{MAX}$ \\
\hline branch width [mm] & 5 & 2.55 & 0.180 & 7.40 & 2.370 & 2.870 \\
endozone width [mm] & 5 & 0.87 & 0.078 & 8.93 & 0.800 & 1.000 \\
aperture width [mm] & 15 & 0.19 & 0.036 & 18.91 & 0.150 & 0.270 \\
aperture spacing [mm] & 10 & 0.05 & 0.018 & 35.10 & 0.025 & 0.075 \\
exilazooecia width [mm] & 15 & 0.08 & 0.023 & 27.88 & 0.050 & 0.012 \\
number of exilazooecia between apertures & 10 & 2.00 & 0.940 & 47.10 & 1.000 & 4.000 \\
exozonal wall thickness [mm] & 10 & 0.06 & 0.020 & 30.49 & 0.050 & 0.010 \\
\hline
\end{tabular}

Fig. 2. Bryozoa from the families Fistulliporidae, Atactotoechidae and Stenoporidae.

A-C - Eofistulotrypa famennensis sp. nov. A: 4/18.2, longitudinal section, scale bar = 2 mm; B: 4/18.2, longitudinal section, scale bar $=1 \mathrm{~mm}$; C: 4/18.1, tangential section, scale bar $=0.5 \mathrm{~mm} ; \mathbf{D}-\mathbf{F}-$ Atactotoechus cellatus sp. nov. D: 4/19.1, longitudinal section, showing wall structure, scale bar $=1 \mathrm{~mm}$; $: 4 / 19.1$, longitudinal section, scale bar $=2$ mm; F: 4/19.1, tangential section, scale bar $=1 \mathrm{~mm}$; G-H - Leptotrypella pojarkovi Orlovski, 1961. G: 4/20a, longitudinal section, scale bar $=1 \mathrm{~mm} ; \mathbf{H}: 4 / 20 \mathrm{a}$, tangential section, scale bar $=0.5 \mathrm{~mm}$; - Nikiforopora jurgensis sp. nov.: 4/21.1, transverse section, scale bar $=0.5 \mathrm{~mm}$. 
Podonino horizon, the Middle-Late Famennian (Late Devonian).

Discussion: Leptotrypella pojarkovi Orlovski, 1961 is similar to Leptotrypella parva Duncan, 1939 from the Traverse Group of North America, but differs from it in a lower number of diaphragms (1-2 vs. 4-6 in L. parva).

Family Stenoporidae Waagen \& Wentzel, 1886

\section{Genus Nikiforopora Dunaeva, 1964}

Type species: Batostomella concentrica Nikiforova, 1927, Early Carboniferous, Ukraine.

Diagnosis: branched colonies with narrow exozone. Autozooecia with oval apertures. Hemiphragms rare; restricted to exozones. Exilazooecia rare. Acanthostyles large, rare. Tubules abundant in different parts of the skeleton. Autozooecial walls thin in endozone; strongly and regularly thickened in exozone.

Occurrence: Eurasia; Late Devonian to Middle Carboniferous.

Discussion: Nikiforopora Dunaeva, 1964 differs from Tabulipora Young, 1883 in having rare diaphragms and regularly thickened walls, from Rhombotrypella Nikiforova, 1933 in having an irregular polygonal section of autozooecia in endozones.

Nikiforopora jurgensis sp. nov. (Figs. 2 I, 3 A-C; Table 4)

Etymology: the specific name refers to the Jurginskaya Formation in which the material was found.

Holotype: 4/21.1; paratypes: 4/21.2-4/21.6. Type locality: Tom River, Kemerovo region, Russia.
Type horizon: Jurginskaya Formation, Podonino horizon, Middle-Late Famennian (Late Devonian).

Diagnosis: colonies branched. Autozooecia with oval apertures. Exilazooecia short and rare. Acanthostyles large, 2-3 surrounding each aperture. Autozooecial diaphragms in the exozone located close to the colony surface.

Description: colonies branched. Exozones 0.65 mm wide. Autozooecial diaphragms complete, rare in endozones. Autozooecial hemiphragms occur in exozones, 1-2 in each autozooecium, located close to the colony surface. Autozooecial walls of $0.012 \mathrm{~mm}$ thick in endozones, $0.075-0.1 \mathrm{~mm}$ thick in exozones. Autozooecia with oval apertures. Exilazooecia short, circular in cross-section, 1-3 surrounding each aperture. Acanthostyles of $0.025-0.05 \mathrm{~mm}$ in diameter, 2-3 surrounding each autozooecial aperture. Tubules abundant, $0.014 \mathrm{~mm}$ in diameter.

Discussion: Nikiforopora jurgensis sp. nov. differs from Nikiforopora rotaji (Trizna, 1958) from the Visean of the Kuzbass in its smaller number of hemiphragms in autozooecia (2-4 vs. 6 in N. rotaji), size of acanthostyles $(0.025-0.05 \mathrm{~mm}$ vs. $0.1-0.15 \mathrm{~mm}$ in $N$. rotaji).

Family Eridotrypellidae Morozova, 1960

Genus Eridotrypella Duncan, 1939

Type species: Batostomella obliqua Ulrich, 1890, Hamilton Group (Middle Devonian), United States of America.

Diagnosis: colonies branched. Autozooecia with irregular-circular apertures. Autozooecial diaphragms in endozones lacking or very rare; variable in number in exozones. Exilazooe-

Table 4. Descriptive statistics for Nikiforopora jurgensis sp. nov. (for abbreviations, see Table 1).

\begin{tabular}{lcccccc}
\hline Nikiforopora jurgensis sp. nov. & $\mathrm{N}$ & $\mathrm{X}$ & $\mathrm{SD}$ & $\mathrm{CV}$ & $\mathrm{MIN}$ & $\mathrm{MAX}$ \\
\hline branch width [mm] & 5 & 2.62 & 0.151 & 5.76 & 2.370 & 2.750 \\
endozone width [mm] & 10 & 1.16 & 0.131 & 11.35 & 1.000 & 1.370 \\
aperture width [mm] & 15 & 0.14 & 0.017 & 12.56 & 0.120 & 0.170 \\
aperture spacing [mm] & 10 & 0.07 & 0.020 & 26.89 & 0.050 & 0.120 \\
exilazooecia width [mm] & 10 & 0.07 & 0.010 & 15.05 & 0.050 & 0.075 \\
number of exilazooecia between apertures & 10 & 1.50 & 0.700 & 47.10 & 1.000 & 3.000 \\
acanthostyle diameter [mm] & 10 & 0.04 & 0.010 & 28.40 & 0.025 & 0.050 \\
\hline
\end{tabular}


cia very rare. Acanthostyles small. Tubules in autozooecial walls common, sometimes completely surrounding acanthostyles. Autozooecial walls thin in endozones, irregularly thickened in exozones.

Occurrence: Eurasia, North America; Late Silurian to Early Carboniferous.

Discussion: Eridotrypella Duncan, 1939 differs from Eostenopora Duncan, 1939 in having only a branched colony, well defined exozones and small acanthostyles.

Eridotrypella tyzhnovi sp. nov. (Figs. 3 D-F; Table 5)

Etymology: the species was named in honour of A.V. Tyzhnov, who studied the Jurga section in detail.

Holotype: 4/22.1; paratype: 4/22.2.

Type locality: Tom River, Kemerovo region, Russia.

Type horizon: Jurginskaya Formation, Podonino horizon, Middle-Late Famennian (Late Devonian).

Diagnosis: colonies branched with narrow exozone. Autozooecia with circular apertures. Exilazooecia rare. Acanthostyles rare and large. Autozooecial walls containing abundant tubules in medium part, thick in exozone.

Description: colonies branched. Branches of 2.37-2.9 $\mathrm{mm}$ in diameter. Endozones $1.37 \mathrm{~mm}$ wide, exozones $0.5-0.75 \mathrm{~mm}$ wide. Autozooecial walls of $0.012 \mathrm{~mm}$ thick in endozones, 0.12 $0.15 \mathrm{~mm}$ thick in exozones. Abundant tubules developed in the middle part of autozooecial walls. Autozooecial diaphragms complete and straight, 1-2 in exozonal parts of autozooecia. Autozooecial apertures circular or oval, measuring $0.1-0.2 \times 0.2-0.25 \mathrm{~mm}$, arranged in step-down places. Exilazooecia rare and short, having a circular form in transversal section, $0.075-0.1 \mathrm{~mm}$ in diameter. Acanthostyles locally 1-2 in number surrounding autozooecial apertures, in some place absent.
Discussion: Eridotrypella tyzhnovi sp.nov. differs from Eridotrypella stellata Tolokononnikova, 2007 from the Upper Famennian of the Kuzbass in smaller number of diaphragms (1-2 vs. 4 in E. stellata), thickness of the autozooecial walls in exozone $(0.12-0.15 \mathrm{~mm}$ vs. $0.028-0.042$ $\mathrm{mm}$ in E. stellata), larger and more rare acanthostyles (1-2 vs. 5-6 acanthostyles per aperture in E. stellata; acanthostyles diameter $0.025-0.050$ $\mathrm{mm}$ vs. $0.014-0.028 \mathrm{~mm}$ in E. stellata).

Order Cryptostomata Vine, 1884

Suborder Rhabdomesina Astrova \& Morozova, 1956

Family Rhomboporidae Simpson, 1895

Genus Rhombopora Meek, 1872

Type species: Rhombopora lepidodendroides Meek, 1872, Late Carboniferous, United States of America.

Diagnosis: colonies ramose. Tube-like autozooecia meet the colony surface at low angles. Diaphragms can occur. Hemisepta absent. Autozooecial apertures oval. Metazooecia rare to absent. One or two acanthostyles at the distal end of each aperture. Exozonal walls with abundant paurostyles arranged in a regular pattern around the apertures.

Occurrence: Eurasia, North America, Australia; Devonian-Permian.

Discussion: The genus Rhombopora Meek, 1872 differs from the genus Klaucena Trizna, 1958 in the shape of the autozooecia and in the absence of large acanthostyles, as well as in having rare metazooecia.

Rhombopora subtilis Nekhoroshev, 1977 (Figs. 3 G-H; Table 6)

1977 Rhombopora subtilis sp. nov., Nekhoroshev, pp. 139-140, pl. 32, figs. 4-7.

Material: single specimen 4/23.

Description: colony thin ramose, $0.8 \mathrm{~mm}$ in diameter. Endozones of $0.2 \mathrm{~mm}$ wide, exozones

Table 5. Descriptive statistics for Eridotrypella tyzhnovi sp. nov. (for abbreviations, see Table 1).

\begin{tabular}{lcccccc}
\hline Eridotrypella tyzhnovi sp. nov. & $\mathrm{N}$ & $\mathrm{X}$ & $\mathrm{SD}$ & $\mathrm{CV}$ & $\mathrm{MIN}$ & $\mathrm{MAX}$ \\
\hline aperture width $[\mathrm{mm}]$ & 15 & 0.15 & 0.034 & 23.28 & 0.100 & 0.20 \\
aperture spacing $[\mathrm{mm}]$ & 10 & 0.09 & 0.015 & 15.20 & 0.075 & 0.12 \\
acanthostyle diameter $[\mathrm{mm}]$ & 10 & 0.04 & 0.012 & 32.27 & 0.025 & 0.05 \\
\hline
\end{tabular}



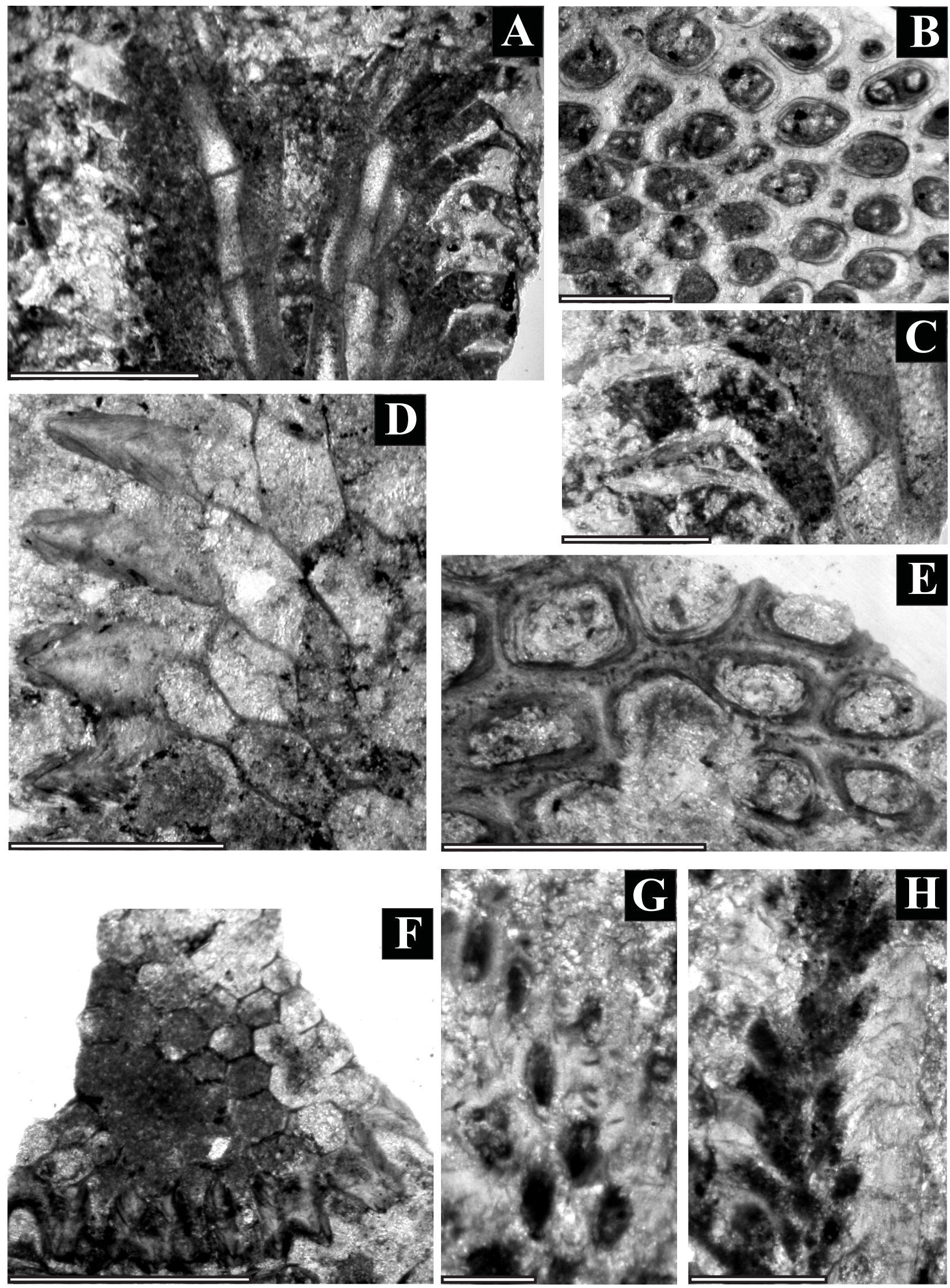
Table 6. Descriptive statistics for Rhombopora subtilis Nekhoroshev,1977 (for abbreviations, see Table 1).

\begin{tabular}{lcccccc}
\hline Rhombopora subtilis Nekhoroshev, 1977 & $\mathrm{~N}$ & $\mathrm{X}$ & $\mathrm{SD}$ & $\mathrm{CV}$ & $\mathrm{MIN}$ & $\mathrm{MAX}$ \\
\hline aperture width [mm] & 7 & 0.06 & 0.013 & 22.00 & 0.050 & 0.075 \\
aperture spacing along branch [mm] & 5 & 0.17 & 0.020 & 12.19 & 0.150 & 0.200 \\
acanthostyle diameter [mm] & 5 & 0.04 & 0.013 & 34.23 & 0.025 & 0.050 \\
aperture spacing across branch [mm] & 5 & 0.13 & 0.013 & 10.01 & 0.120 & 0.150 \\
\hline
\end{tabular}

of $0.3 \mathrm{~mm}$ wide. Autozooecial walls of 0.025 $\mathrm{mm}$ in the thickness the endozones, $0.075-0.1$ $\mathrm{mm}$ thickness in exozones. Hemisepta absent. Autozooecial apertures elongate-oval, measuring on average $0.06 \times 0.12 \mathrm{~mm}$. One acanthostyle on the distal end of aperture, $0.025-0.05 \mathrm{~mm}$ in diameter. Paurostyles $0.010 \mathrm{~mm}$ in diameter arranged around each aperture.

Occurrence: Kazakhstan: Sulcifer horizon, Middle Famennian (Late Devonian); Transcaucasia: Early Famennian; Kemerovo region, Russia: Podonino horizon, Middle-Late Famennian (Late Devonian).

Discussion: Rhombopora subtilis Nekhoroshev, 1977 from the Middle Famennian of Kazakhstan is similar to Rhombopora lepidodendroides Meek, 1872 from the Late Carboniferous, United States of America, but differs in having smaller colonies (0.8 mm vs. $1.2-1.5 \mathrm{~mm}$ in diameter in $R$. lepidodendroides).

Genus Klaucena Trizna, 1958

Type species: Klaucena immortalis Trizna, 1958, Early Carboniferous, Kuzbass, Russia.
Diagnosis: colonies branched with incomplete mesotheca. Few diaphragms and hemisepta. Autozooecial apertures irregular-oval or ovalrhombic. Abundant macroacanthostyles and paurostyles. Autozooecial walls thin in endozone; regularly thickened in exozone.

Occurrence: Russia, China; Early Carboniferous and Early Permian.

Discussion: the genus Klaucena Trizna, 1958 differs from the genus Rhombopora Meek, 1872 in the shape of the autozooecia and in the presence of macroacanthostyles and hemisepta.

Klaucena gracilis sp. nov. (Figs. 4 A-C; Table 7) Etymology: The specific name 'gracilis' refers to the habit of the colony (derived from Latin 'gracilis' = slender).

Holotype: 4/24.1; paratypes: 4/24.2-4/24.4.

Type locality: Tom River, Kemerovo region, Russia.

Type horizon: Jurginskaya Formation, Podonino horizon, Middle-Late Famennian (Late Devonian).

Table 7. Descriptive statistics for Klaucena gracilis sp. nov. (for abbreviations, see Table 1).

\begin{tabular}{lrrrrrr}
\hline Klaucena gracilis sp. nov. & $\mathrm{N}$ & $\mathrm{X}$ & $\mathrm{SD}$ & $\mathrm{CV}$ & $\mathrm{MIN}$ & $\mathrm{MAX}$ \\
\hline branch width [mm] & 5 & 0.80 & 0.075 & 9.39 & 0.720 & 0.900 \\
endozone width [mm] & 5 & 0.21 & 0.029 & 14.18 & 0.170 & 0.250 \\
aperture width [mm] & 10 & 0.06 & 0.012 & 21.00 & 0.050 & 0.075 \\
aperture length [mm] & 10 & 0.16 & 0.008 & 5.10 & 0.150 & 0.170 \\
aperture spacing across branch [mm] & 10 & 0.14 & 0.021 & 15.14 & 0.120 & 0.170 \\
aperture spacing along branch [mm] & 10 & 0.07 & 0.022 & 32.80 & 0.050 & 0.100 \\
macroacanthostyle diameter [mm] & 10 & 0.01 & 0.004 & 28.06 & 0.012 & 0.025 \\
number of macroacanthostyle between apertures & 10 & 4.30 & 0.674 & 15.69 & 4.000 & 6.000 \\
\hline
\end{tabular}

Fig. 3. Bryozoa from the families Stenoporidae, Eridotrypellidae and Rhomboporidae.

A-C - Nikiforopora jurgensis sp. nov. A: 4/21.1, longitudinal section, scale bar $=1 \mathrm{~mm}$; B: 4/21.2, tangential section, scale bar = $0.5 \mathrm{~mm}$; C: $4 / 21.3$, longitudinal section, showing exilazooecia, scale bar $=0.2 \mathrm{~mm}$; D-F - Eridotrypella tyzhnovi sp. nov. D: 4/22.1, longitudinal section, scale bar $=0.5 \mathrm{~mm} ; \mathrm{E}: 4 / 22.1$, tangential section, scale bar $=0.5 \mathrm{~mm}$; F: 4/22.1, transverse section, scale bar $=1 \mathrm{~mm}$; G-H - Rhombopora subtilis Nekhoroshev, 1977. G: 4/23, tangential section, scale bar $=0.2 \mathrm{~mm} ; \mathbf{H}: 4 / 23$, longitudinal section, scale bar $=0.5 \mathrm{~mm}$. 

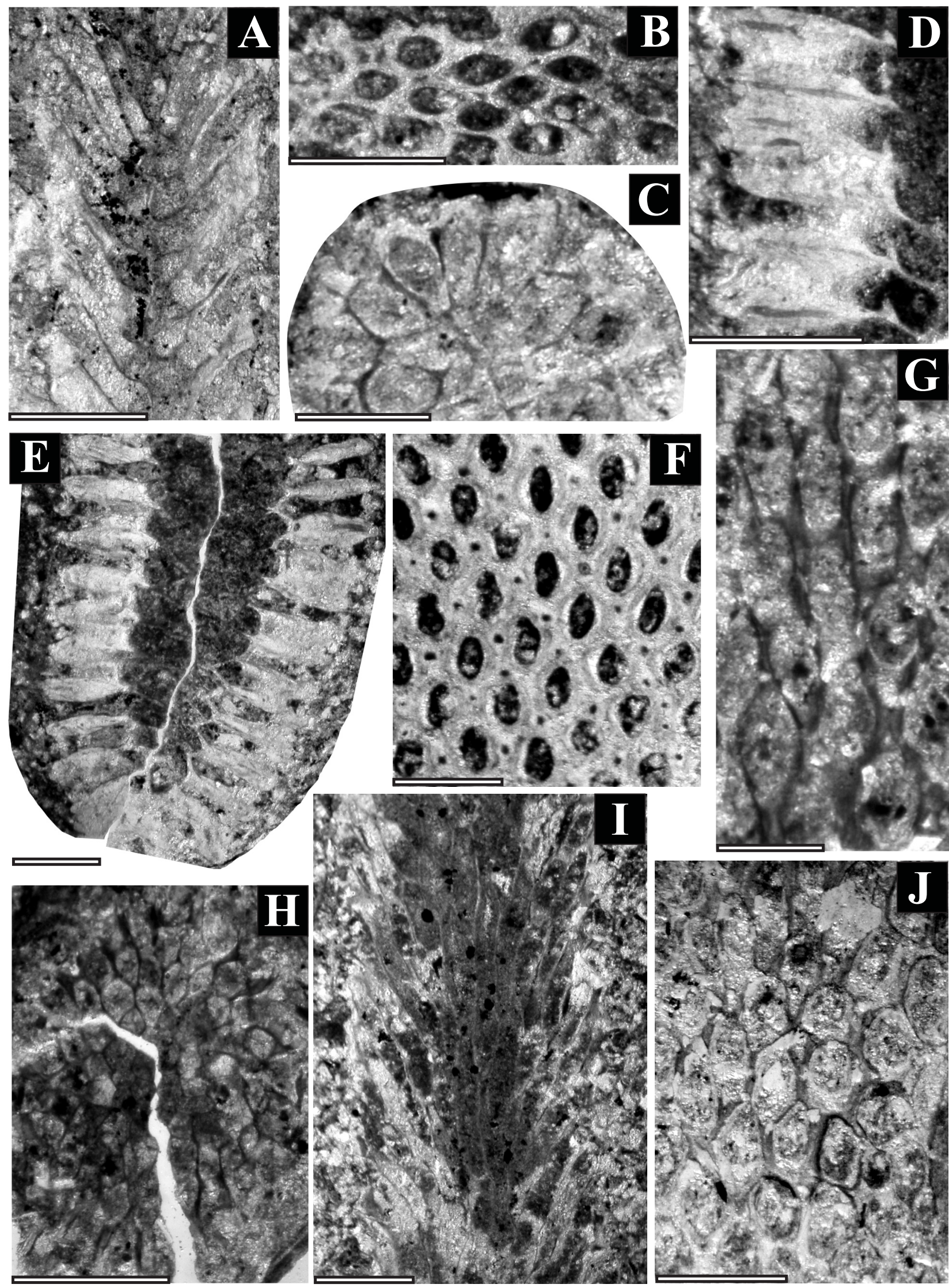
Diagnosis: colonies branched. Diaphragms and hemisepta not observed. Autozooecia with oval-rhombic apertures. Macroacanthostyles and paurostyles arranged around each autozooecial aperture in various numbers.

Description: colonies branched dichotomous. Mesotheca incomplete, slightly wavy, 0.025 $\mathrm{mm}$ in thickness. Exozones $0.25-0.3 \mathrm{~mm}$ wide. Autozooecial walls of $0.012 \mathrm{~mm}$ thick in endozones, and 0.025-0.05 mm thick in exozones. Autozooecial apertures oval-rhombic, arranged in regular diagonal rows. Macroacanthostyles surrounding each autozooecial aperture. Paurostyles rare, $0.01 \mathrm{~mm}$ in diameter, arranged in groups.

Discussion: Klaucena gracilis sp.nov. differs from Klaucena aculeus Trizna, 1958 from the Tournaisian (Early Carboniferous) of the Kuzbass in the size of the autozooecial apertures $(0.05-0.075 \times 0.15-0.17 \mathrm{~mm}$ vs. $0.20 \times 0.17 \mathrm{~mm}$ in Klaucena aculeus), and in smaller macroacanthostyles (0.012-0.025 mm vs. $0.04-0.08 \mathrm{~mm}$ in Klaucena aculeus).

Klaucena lalolamina Yang, Hu, Xia, 1988 (Figs. 4 D-F; Table 8)

1988 Klaucena lalolamina sp. n., Yang, Hu, Xia, pp. 175-176, pl. 33, figs. 4-7.

Material: 4/25.1-4/25.2.

Description: colonies flattened and branched, $1.75 \mathrm{~mm}$ thick; width of a fragment $2.5 \mathrm{~mm}$. Exozones $0.75 \mathrm{~mm}$ wide. Autozooecial walls $0.025 \mathrm{~mm}$ thick in endozones, and $0.1 \mathrm{~mm}$ thick in exozones. Diaphragms not observed. Long inferior hemisepta present. Autozooecial aper- tures oval, arranged in regular diagonal rows. 3-5 Macroacanthostyles surround each autozooecial apertures, $0.05-0.075 \mathrm{~mm}$ in diameter. Paurostyles abundant, $0.01 \mathrm{~mm}$ in diameter, located in groups or irregularly between autozooecial apertures and macroacanthostyles.

Occurrence: China: Mengkungao Formation, Early Carboniferous; Russia: Podonino horizon, the Middle-Late Famennian (Late Devonian).

Discussion: Klaucena lalolamina Yang, Hu, Xia, 1988 differs from other species of the genus in having a flattened and ramose colony.

\section{Family Nikiforovellidae Gorjunova, 1975}

\section{Genus Mediapora Trizna, 1958}

Type species: Mediapora injaensis Trizna, 1958, Early Carboniferous, Kuzbass, Russia.

Diagnosis: colonies branched. Diaphragms rare. Hemisepta absent. Autozooecia with elongated oval apertures. Acanthostyles located at junctions of autozooecial apertures. Rare metazooecia present.

Occurrence: Russia, Kazakhstan, Mongolia; Middle Devonian to Early Carboniferous.

Discussion: Mediapora Trizna, 1958 differs from Nikiforovella Nekhoroshev, 1948 in having few diaphragms, its absence of a well-marked median axis and its presence of few metazooecia.

Mediapora elegans sp. nov. (Figs. 4 G-J; Table 9) Etymology: The specific name' elegans' refers to the small size and general delicate appearance of the new species (derived from Latin 'elegantis' $^{\prime}=$ elegant).

Table 8. Descriptive statistics for Klaucena lalolamina Yang, Hu, Xia, 1988 (for abbreviations, see Table 1).

\begin{tabular}{lcccccc}
\hline Klaucena lalolamina Yang, Hu, Xia, 1988 & $\mathrm{N}$ & $\mathrm{X}$ & $\mathrm{SD}$ & $\mathrm{CV}$ & $\mathrm{MIN}$ & MAX \\
\hline aperture width [mm] & 20 & 0.09 & 0.020 & 20.93 & 0.050 & 0.120 \\
aperture spacing along branch [mm] & 15 & 0.19 & 0.024 & 12.61 & 0.150 & 0.220 \\
aperture spacing across branch [mm] & 15 & 0.20 & 0.033 & 16.27 & 0.150 & 0.250 \\
macroacanthostyle diameter [mm] & 10 & 0.06 & 0.017 & 29.13 & 0.025 & 0.075 \\
number of macroacanthostyle between apertures & 15 & 4.06 & 0.593 & 14.59 & 3.000 & 5.000 \\
\hline
\end{tabular}

Fig. 4. Bryozoa from the families Rhomboporidae and Nikiforovellidae.

A-C - Klaucena gracilis sp. nov. A: 4/24.1, longitudinal section, scale bar $=0.5 \mathrm{~mm}$; B: 4/24.1, tangential section, scale bar $=0.5 \mathrm{~mm}$; C: 4/24.2, transverse section, scale bar $=0.2 \mathrm{~mm}$; D-F - Klaucena lalolamina Yang, Hu, Xia, 1988. D: $4 / 25.1$, longitudinal section, scale bar $=0.5 \mathrm{~mm}$; E: 4/25.1, transverse section, scale bar $=0.5 \mathrm{~mm} ; \mathrm{F}: 4 / 25.1$, tangential section, scale bar $=0.5 \mathrm{~mm}$; G-J - Mediapora elegans sp. nov. G: 4/26.1, tangential section, scale bar $=0.2 \mathrm{~mm}$; H: 4/26.1, transverse section, scale bar $=0.5 \mathrm{~mm} ; \mathrm{I}: 4 / 26.2$, longitudinal section, scale bar $=0.5 \mathrm{~mm}$; J: 4/26.2, tangential section, scale bar $=0.2 \mathrm{~mm}$. 
Table 9. Descriptive statistics for Mediapora elegans sp. nov. (for abbreviations, see Table 1).

\begin{tabular}{lrrrrrr}
\hline Mediapora elegans sp. nov. & $\mathrm{N}$ & $\mathrm{X}$ & $\mathrm{SD}$ & $\mathrm{CV}$ & $\mathrm{MIN}$ & $\mathrm{MAX}$ \\
\hline branch width [mm] & 5 & 1.64 & 0.314 & 19.13 & 1.200 & 2.000 \\
endozone width [mm] & 5 & 0.53 & 0.088 & 16.51 & 0.400 & 0.620 \\
aperture width [mm] & 10 & 0.12 & 0.022 & 18.45 & 0.100 & 0.170 \\
aperture length [mm] & 10 & 0.25 & 0.018 & 7.64 & 0.220 & 0.270 \\
metazooecia diameter [mm] & 5 & 0.05 & 0.017 & 35.35 & 0.025 & 0.075 \\
\hline
\end{tabular}

Holotype: 4/26.1; paratypes: 4/26.2-4/26.3. Type locality: Tom River, Kemerovo region, Russia.

Type horizon: Jurginskaya Formation, Podonino horizon, Middle-Late Famennian (Late Devonian).

Diagnosis: colonies thin branched. Few diaphragms. Autozooecia with long-oval apertures. Rare metazooecia. Acanthostyles numerous. Longitudinal ridges presents.

Description: colonies thin, branched. Exozones 0.4-0.7 mm wide. Autozooecial walls 0.012 $\mathrm{mm}$ thick in endozones, and $0.025 \mathrm{~mm}$ thick in exozones. Diaphragms few, straight, complete or incomplete. Autozooecial apertures elongated, oval, arranged in regular diagonal rows. 5 Acanthostyles surround the autozooecial apertures, $0.025 \mathrm{~mm}$ in diameter. Metazooecia rare, $0.025-0.075 \mathrm{~mm}$ in diameter.

Discussion: Mediapora elegans sp. $n$. differs from Mediapora rhombicellata Trizna, 1958 from the Tournaisian (Early Carboniferous) of the Kuzbass in its smaller size of acanthostyles $(0.025$ $\mathrm{mm}$ vs. $0.04-0.05 \mathrm{~mm}$ in Mediapora rhombicellata), and in the presence of metazooecia.

\section{Discussion}

The bryozoan fauna from the Jurginskaya Formation shows palaeobiogeographical affinities with Kazakhstan, Kirgizia, Transcaucasia, China, and the United States of America (Fig. 5). Rhombopora subtilis Nekhoroshev, 1977 and Leptotrypella pojarkovi Orlovski, 1961 are known from the Mesoplica meisteri Brachiopod Zone of the Lower Famennian of Transcaucasia (Nakhichevan, Azerbaijan) (Lavrentjeva, 1985). The species is also known from the Sulcifer Horizon (Middle Famennian) of central Kazakhstan and from the Middle Famennian of the west- ern offshoots of the Tian Shan (Chatkal-Narynskaya area), respectively (Orlovski, 1961; Nekhoroshev, 1977). Klaucena lalolamina Yang, Hu, Xia, 1988 is known from the lower part of the Mengkungao Formation (Tournaisian, Early Carboniferous) of China (Yang et al., 1988).

Most bryozoans from the Jurga section are new species of the genera Eofistulipora, Atactotoechus, Nikiforopora, Eridotrypella, Klaucena, and Mediapora. The genera Atactotoechus and Eridotrypella are more widely distributed in the Famennian. Six species of Atactotoechus are known from the Famennian of Kazakhstan, Kirgizia, China, and three species of Eridotrypella are known from the Famennian of the United States, Kazakhstan, and Kuzbass (Fritz, 1944; Yang, 1950; Orlovski, 1961; Troitzkaya, 1968, 1975; Tolokonnikova, 2007). The spatial distribution of three other genera was restricted in the Famennian: Eofistulipora is known from China, Klaucena from Kazakhstan and Transcaucasia, and Mediapora from Transcaucasia (Troitzkaya, 1975; Lavrentjeva, 1985; Xia, 1997). It is worthwhile to mention here that the Tournaisian was the time-span of a peak in the

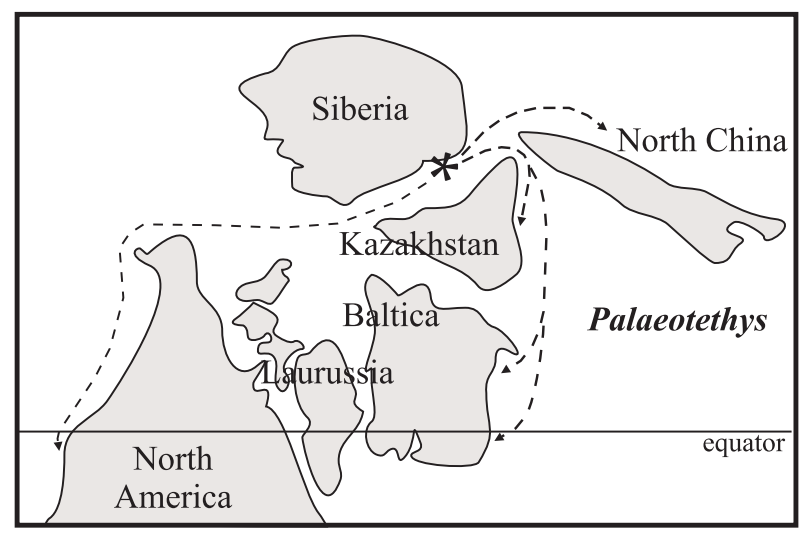

Fig. 5. Palaeobiogeography of genera from the Jurginskaya Formation in Famennian (plate tectonic reconstruction after Scotese, 2001). The asterisk indicates the Jurga section. 
development of the genera Klaucena and Mediapora, which include 10 and 3 species, respectively. Their distribution comprised Kuzbass, China, Kazakhstan, and Mongolia. The finding of a representative of Nikiforopora extends the stratigraphic range of this genus. This genus has previously been reported from the Mississippian of Russia, Uzbekistan, Mongolia, and Ukraine (Dunaeva, 1964; Astrova, 1978; Morozova et al., 2003).

\section{Acknowledgements}

Dr. Jaroslav Gutak (Kuzbass Academy, Russia) is thanked for extensive support of this research. Comments on the manuscript from Dr. Dmitry Ruban (Southern Federal University, Russia) are highly appreciated. I am grateful to Dr. Andrej Ernst (Kiel University, Germany) for his help with literature and constructive review. Dr. Urszula Hara (Polish Geological Institute, Warsaw) is thanked sincerely for critical reading of the manuscript and helpful comments.

\section{References}

Astrova, G.G., 1964. Novyi otryad paleozoiskikh mshanok [New order of Palaeozoic bryozoans]. Paleontologicheskij Zhurnal 1, 22-31.

Astrova, G.G., 1965. Morphologiya, istoriya razvitiya i sistema ordovikskich i siluriiskikh mshanok [Morphology, developmental history and system of the Ordovician and Silurian bryozoans]. Trudy Paleontologicheskogo Instituta Akademii Nauk SSSR 106, 1-432.

Astrova, G.G., 1978. Istoriya razvitiya, sistema i filogenia mshanok: Otryad Trepostomata [Developmental history, system, and phylogeny of the bryozoans: order Trepostomata]. Trudy Paleontologicheskogo Instituta Akademii Nauk SSSR 169, 1-240.

Astrova, G.G. \& Morozova, I.P., 1956. Sistematika mshanok otryada Cryptostomata [Systematics of the order Cryptostomata]. Doklady Akademii Nauk SSSR 110, 661-664.

Babin, G.A., Borisov, G.A. \& Tokarev, V.N., 1999. Legenda Kuzbasskoi serii gosudarstvenoi geologicheskoi karty RF mashtaba 1:200000 [Legend of the Kuzbass Serie of the State Geological Map of the Russian Federation, scale 1:200000], $426 \mathrm{pp}$.

Bassler, R.S., 1929. The Permian Bryozoa of Timor. Paläontologie von Timor 16, 37-90.

Boardman, R.S., Cheetham, A.H., Blake, D.B. \& Cook, P.L., 1983. Introduction, Order Cystoporata, Order Cryptostomata. [In:] Robison, R.A. (Ed.): Treatise on invertebrate paleontology. Part. G: Bryozoa (revised). University of Kansas Press 1, 1-625.
Borg, F. 1926. Studies of recent cyclostomatous Bryozoa. Zoologiska Bidrag fran Uppsala 10, 181-507.

Duncan, H., 1939. Trepostomatous Bryozoa from the Traverse Group of Michigan. University of Michigan Paleontology Contributions 5 (10), 171-120.

Dunaeva, N.N., 1964. Novye mshanki otryada Trepostomata iz nizhnego karbona Donetskogo basseina [New bryozoans from the order Trepostomata from the Lower Carboniferous of the Donetsk Basin]. Paleontologicheskij Zhurnal 2, 39-44.

Ehrenberg, C.G., 1831. Animalia invertebrata exclusis insects. Symbolae physicae, seu icones et descriptiones corporum naturalium novorum aut minus cognitorum. Pars Zoologica, Vol. 4. Mittler, Berlin, 831 pp.

Fritz, M.A., 1944. Upper Devonian Bryozoa from New Mexico. Journal of Paleontology 18, 31-41.

Gorjunova, R.V., 1975. Permskie mshanki Pamira [Permian bryozoans of the Pamir]. Trudy Paleontologicheskogo Instituta Academiyi Nauk SSSR 148, 125 pp.

Gutak, J.M. \& Tolokonnikova, Z.A., in press. Jurginskya svita (famenskii yarus) severnogo obramleniya Kuzbassa (paleontologicheskii phenomen) [The Jurginskaya Formation, Famennian of the northern border of Kuzbass (palaeontological phenomenon)]. [In:] Podobina, V.B. (Ed.): Evolution of life on Earth. Proceedings of International Conference. Tomsk.

Köhler, W., Schachtel, G. \& Voleske, P., 1996. Biostatistik. Einführung in die Biometrie für Biologen und Agrarwissenschaftler. Springer, Berlin, 285 pp.

Kraevskaya, L.N., 1960. Spiriferidy verchnejurginskoi tolshi i ich vozrast [Spiriferids of the Upper Jurgensis bed and its age]. Trudy TGU (New series) 146, 29-36.

Lavrentjeva, V.D., 1985. Verchnedevonskie mshanki Zakavkazjya [Late Devonian bryozoans of Transcaucasia]. Izvestiya Vysshikh Uchebnykh Zavedeniy. Geologiya i Razvedka, Ministerstvo Vysshego i Srednego Obrazovaniya 8, 12-18.

Meek, F.B., 1872. Report on the paleontology of eastern Nebraska. [In:] Hayden, F.V. (Ed.): Final report on the United States Geological Survey of Nebraska and portions of adjacent territories. U.S. Government Printing Office, Washington, 81-239.

Morozova, I.P., 1959. Novyi rod mshanok semeistva Fistuliporidae iz devona Kuznetsogo basseina [A new bryozoan genus of the family Fistuliporidae from the Devonian of the Kuznetsk Basin]. Paleontologicheskij Zhurnal 2, 79-81.

Morozova, I.P., 1960. Devonskie mshanki Minusinskikh i Kuznetskoi kotlovin [Devonian bryozoans of the Minusinsk and Kuznetsk depressions]. Trudy Paleontologicheskogo Instituta Academiyi Nauk SSSR 86, 207 pp.

Morozova, I.P., Gorujnova, R.V. \& Ariunchimeg, Y., 2003. Mshanki [Bryozoans]. [In:] Rozanov, A. Ju. (Ed.): Palaeontology of Mongolia, $168 \mathrm{pp}$.

Nekhoroshev, V.P., 1948. Kamennougolnie mshanki severo-vostochnogo Pribalchashjya [Carboniferous bryozoans from the north-eastern Balkhash Lake region]. Akademiya Nauk Kazakhskoi SSR Alma-ata, 70 pp.

Nekhoroshev, V.P., 1977. Devonskie mshanki Kazakhstana [Devonian bryozoans of Kazakhstan]. Trudy VSEGEI (New series) 186, 1-192. 
Nicholson, H.A., 1874. Descriptions of new fossils from the Devonian Formation of Canada West. Geological Magazine 1, 51-96.

Nikiforova, A.I., 1933. Karbon Srednei Azii. Materialy k poznaniu mshanok Turkestana [The Carboniferous of Middle Asia. Material for the knowledge of bryozoans from Turkestan]. Trudy VSEGEI 207, 77 pp.

Orlovski, M.B., 1961. Novye famenskie mshanki iz Chatkalo-Naryn zonu Tian Shan [New Famennian bryozoan species from the Chatkalo-Naryn zone of Tian Shan]. Paleontologicheskii Zhurnal 2, 64-71.

Scotese, C.R., 2001. Digital paleogeographic map archive on CD-ROM. PALEOMAP Project. University of Texas (Arlington). http://www.scotese.com (PALEOMAP website).

Simpson, G.B., 1895. A handbook of the genera of the North American Palaeozoic Bryozoa. New York State Geological Survey Annual Reports 14, 403-669.

Tolokonnikova, Z.A., 2007. Mshanki abushevskogo gorizonta Kusbassa [Bryozoans from the Abushevo horizon of the Kusbass]. Vestnik of the Tomsk State University 297, 171-174.

Trizna, V.B., 1958. Rannekamennougolnye mshanki Kuznetzkoi kotloviny [Early Carboniferous bryozoans of the Kuznetzk depression]. Trudy VNIGRI, Microfauna of the USSR 122, $433 \mathrm{pp}$.

Troitzkaya, T.D., 1968. Devonskie mshanki Kazakhstana [Devonian bryozoans of Kazakhstan]. Moscow, Nedra, 239 pp.

Troitzkaya, T.D., 1975. Osnovnye osobennosti mshanok Centralnogo Kazachstana na granitce devona i karbona [Main features of bryozoans in Central Kazakhstan at the boundary between the Devonian and the Carboniferous]. Paleontologicheskij Zhurnal 9, 323-339.

Ulrich, E.O., 1882. American Paleozoic Bryozoa. The Journal of the Cincinnati Society of Natural History 5, 233257.
Ulrich, E.O., 1883. American Paleozoic Bryozoa. The Journal of the Cincinnati Society of Natural History 6, 245279.

Ulrich, E.O. \& Bassler, R.S., 1904. A revision of the Paleozoic Bryozoa. Part II: on genera and species of Trepostomata. Bulletin of the US Geological Survey 173, 15-55.

Vinassa de Regny, P., 1921. Sulla classificazione dei Trepostomidi. Societa Italiana di Scienze Naturali Atti 59, 212-231.

Vine, G.R., 1884. Fourth report of the Committee appointed for the purpose of reporting on fossil Polyzoa. Report of the 53th meeting of the British Association for the Advancement of Science, 161-209.

Waagen, W. \& Wentzel, I., 1886. Salt Range Fossils. Pt. Coelenterata. Memoir of the Geological survey of India. Palaeontologica Indica 13, 835-924.

Xia, F.S., 1997. Marine microfaunas (bryozoans, conodonts and microvertebrate remains) from the Frasnian-Famennian interval in northwestern Junggar Basin of Xinjiang in China. Beiträge zur Paläontologie 22, 91-207.

Yang, K.C., 1950. Some Bryozoa from Upper Devonian and Lower Carboniferous of Huan. Paleontological Society of China 6, 1-16.

Yang, K.C., Hu, Z.X. \& Xia, F., 1988. Bryozoans from Late Devonian and Early Carboniferous of Central Hunan. Palaeontologia Sinica 174 (New series B 23), 197 pp.

Young, J., 1883. On Ure's «Millepore», Tabulipora (Cellepora) Urei Fleming. Annals and Magazine of Natural History (series 5) 12, 154-158.

Manuscript received 28 May 2010 revision accepted 28 August 2010 